\title{
ANALISIS KARAKTERISTIK STOMATA PADA DAUN TANAMAN \\ BAMBU REJEKI (Dracaena reflexa) SEBAGAI TANAMAN HIAS PENYERAP POLUSI DI KAWASAN KOTA MALANG
}

\author{
Juma'ani $^{1}$ dan Anita Munawwaroh ${ }^{2}$ \\ ${ }^{1}$ Mahasiswa IKIP Budi Utomo, Jl. Citandui No. 46 Malang \\ ${ }^{2}$ Dosen IKIP Budi Utomo, Jl. Citandui No. 46 Malang \\ e-mail: jumaani95@gmail.com
}

\begin{abstract}
Air pollution is changes of air arrangement from its normal state that is caused by the ingress of foreign materials or substances in the air. The resulting pollutants include $\mathrm{SO}_{2}, \mathrm{NO}_{2}, \mathrm{CO}_{2}, \mathrm{O}_{3}$, hydrocarbons, and heavy metals such as lead $(\mathrm{Pb})$, zinc ( $\mathrm{Zn})$ and cadmium (Cd). The impact of plant's vehicle exhaust gas is seen from the leaf mesophyll damage especially in the palisade tissue and the reduced number of stomata. Responding to the problem, conducted research with the aim to know the influence of pollution on the amount of stomata on the plant bamboo rejeki (Dracaena reflexa) as ornamental plants absorb pollution in the area of Malang city using the method of polishing the acne (aceton). The results showed that the number of stomata in polluted areas of vehicle pollution decreased at each point compared to areas not polluted by vehicles. In the contaminated area the average number of stomata is at point one 49 , the second point 42.5 , and the third point 37 , whereas in the area that is not contaminated with the average number of stomata at point one 60.5, the second point is 68 , and the point three is 70,5. Damage or Decrease in the number of stomata occurs due to the entry of gas that is toxic through stomata with diffusion process, so that the liquid composition of the cell becomes disturbed and the cell becomes damaged and dead.
\end{abstract}

Keywords: Stomata, Dracaena reflexa, Characteristic.

\section{PENDAHULUAN}

Pencemaran udara merupakan berubahnya susunan udara dari keadaan normalnya yang disebabkan oleh masuknya bahan atau zat asing didalam udara. Udara pada daerah perkotaan sudah terkontaminasi oleh zat-zat dan gas-gas beracun yang disebabkan oleh bertambah banyaknya kendaraan bermotor yang menggunakan bahan bakar. Kelangsungan hidup manusia, hewan dan tumbuhan akan terganggu dengan adanya bahan atau zat asing dalam udara dengan jumlah tertentu serta dalam waktu yang cukup lama (Pohan, 2002).

Kegiatan transportasi dan industriakan menghasilkan limbah berupa asap, gas-gas beracun, ataupun partikulat debu yang dapat mencemari udara dan lingkungan di sekitarnya. Molekul yang di hasilkan antara lain; $\mathrm{SO}_{2}, \mathrm{NO}_{2}, \mathrm{CO}_{2}, \mathrm{O}_{3}$, hidrokarbon, dan logam-logam berat seperti timbal $(\mathrm{Pb})$, seng (Zn) dan cadmium (Cd). Molekul yang terdapat pada emisi gas buang kendaraan baik dalam bentuk padat dan cairan yang dapat mengendap dalam partikel debu (Rachmawati, 2006).

Molekul yang dihasilkan dari asap kendaraan bermotor apabila terhirup oleh makhluk hidup dapat mengakibatkan kerusakan pada organ dan bila melebihi jumlah tertentu akan menyebabkan kematian. Pada tumbuhan berakibat terhadap rusaknya mesofil daun khususnya pada jaringan palisade dan berkurangnya jumlah stomata. 
Salah satu jenis tanaman yang banyak di kawasan Arjosari Kota Malang adalah tanaman Bambu Rejeki (Dracaena reflexa). Dracaena reflexa merupakan tanaman hias jalan yang mampu menyerap polutan. Penelitian sebelumnya yang dilakukan oleh Fatia dkk (2015) menyebutkan Dracaena reflexa merupakan tanaman semak yang mampu menyerap logam berat $\mathrm{Pb} . \mathrm{Pb}$ merupakan salah satu unsur yang digunakan sebagai campuran bahan bakar bensin, yang berfungsi meningkatkan daya pelumasan dan meningkatkan efisiensi pembakaran pada bahan bakar. Jika terhirup oleh manusia, $\mathrm{Pb}$ dapat menimbulkan dampak serius pada kesehatan manusia misalnya gangguan pernapasan, gangguan pada tulang, hati, paruparu, ginjal, limpa, jantung, otak, gigi dan rambut.Salah satu upaya untuk menanggulangi pengaruh logam $\mathrm{Pb}$, yaitu dengan cara memanfaatkan tanaman hias yang ada di pinggir jalan. Tanaman hias jalan dengan ukuran yang lebih kecil dan setinggi knalpot kendaraan bermotor berpotensi sebagai penyerap polutan (Nasrullah, 2000).

Kawasan Arjosari kota Malang merupakan kawasan dengan lintasan kendaraan yang cukup padat. Semakin banyak kendaraan yang mengeluarkan asap (gas) maka akan menimbulkan dampak negatif terhadap lingkungan sekitar. Oleh sebab itu, perlu dilakukan penelitian untuk mengetahui pencemaran udara dengan melihat jumlah stomata pada tanaman hias jalan yang mampu menyerap polutan di kawasan Arjosari Kota Malang.

Penelitian ini dilakukan untuk mengetahui karakteristik stomata pada tanaman Dracaena reflexa sebagai tanaman hias penyerap polusi di kawasan Kota Malang.

\section{METODE PENELITIAN}

Penelitian ini dilaksanakan di Laboratorium IKIP Budi Utomo Malang pada Bulan Mei 2017. Pengambilan sampel dilakukan pada 2 lokasi, yaitu lokasi tercemar polusi kendaraan bermotor dan lokasi tidak tercemar polusi kendaraan bermotor. Pada lokasi yang tercemar polusi, sampel diambil di 3 tempat, yaitu Jl. Letjen S. Parman, Jl. Achmad Yani, dan Jl. Raden Intan sedangkan lokasi yang tidak tercemar pousi sampel juga diambil di 3 tempat, yaitu kawasan perkampungan Kelurahan Kauman, yaitu di Jl. Semeru, Jl. Basuki Rachmad, dan Jl. A.R. Hakim.

Alat yang digunakan dalam penelitian ini, yaitu gunting, kantong plastik, kertas label, mikroskop, kaca benda, kamera, isolasi, tisu, dan alat tulis. Bahan yang digunakan dalam penelitian ini adalah sampel daun, kutek, dan aquades.

\section{Prosedur Kerja}

Prosedur pengamataan menggunakan metode pengolesan kutek (aceton). Daun di bilas hingga bersih kemudian sampel daun dilap menggunakan tisu agar kotorannya hilang. Olesi sampel dengan kutek dengan lebar $\pm 1.5 \mathrm{~cm}$ pada bagian tengah bawah daun, tunggu sampai kering. Tempeli sampel yang sudah diolesi kutek dengan selotip, kemudian tarik selotip dan tempelkan pada kaca benda. Amati di bawah mikroskop dengan pembesaran 40x. Dihitung jumlah stomata yang terdapat pada tiap luas bidang pandang sebanyak 5 kali penampang. Pengamatan terhadap karekteristik stomata meliputi bentuk stomata, tipe stomata dan bentuk sel penutup stomata (Hidayat,1995). 


\section{Analisis Data}

Data hasil pengamatan dianalisis secara deskriptif menggunakan angka, gambar ataupun grafik dan tabel, agar bisa memberikan keterangan tentang jumlah stomata antara daerah tercemar polusi udara dan daerah yang tidak tercemar polusi udara.

\section{HASIL DAN PEMBAHASAN}

Hasil penelitian analisis karakteristik stomata pada daun Dracaena reflexa sebagai tanaman hias penyerap polusi di kawasan Kota Malang dengan menggunakan metode pengolesan kutek (aceton). Data yang diperoleh berupa data karakteristik dan jumlah stomata pada daun Dracaena reflexa sebagai tanaman hias penyerap polusi dengan lokasi pengambilan sampel yang berbeda. Dimana data karakteristik dan jumlah stomata dapat dilihat pada Tabel 1 sebagai berikut:

Tabel 1. Karakteristik Stomata pada Tanaman Dracaena reflexa

\begin{tabular}{cccc}
\hline \multirow{2}{*}{ Tanaman } & \multicolumn{3}{c}{ Karakteristik Stomata } \\
\cline { 2 - 4 } & $\begin{array}{c}\text { Bentuk } \\
\text { stomata }\end{array}$ & $\begin{array}{c}\text { Bentuk sel } \\
\text { penutup }\end{array}$ & Tipe \\
\hline Dracaena reflexa & Oval & Ginjal & Diasitik \\
\hline
\end{tabular}

Berdasarkan Tabel 1, karakteristik stomata pada tanaman Dracaena reflexa memiliki bentuk oval dan didampingi oleh sel penutup yang berbentuk seperti ginjal dengan sel tetangga yang sejajar, tipe stomata diasitik. Pada tipe diasitik setiap stomata dikelilingi oleh dua sel tetangga (Arisanti, 2005).

Berdasarkan hasil penelitian menunjukkan bahwa jumlah stomata pada lokasi yang tercemar mengalami penurunan pada tiap titiknya dengan rata-rata jumlah stomata titik satu 49, titik dua 42.5, dan titik tiga 37 sedangkan lokasi yang tidak tercemar dengan rata-rata jumlah stomata pada titik satu 60.5, titik dua 68, dan titik tiga 70,5 (Gambar 1). Perbedaan jumlah stomata tersebut diduga karena adanya perbedaan kondisi lingkungan dan ketahanan stomata terhadap zat pencemar pada udara.

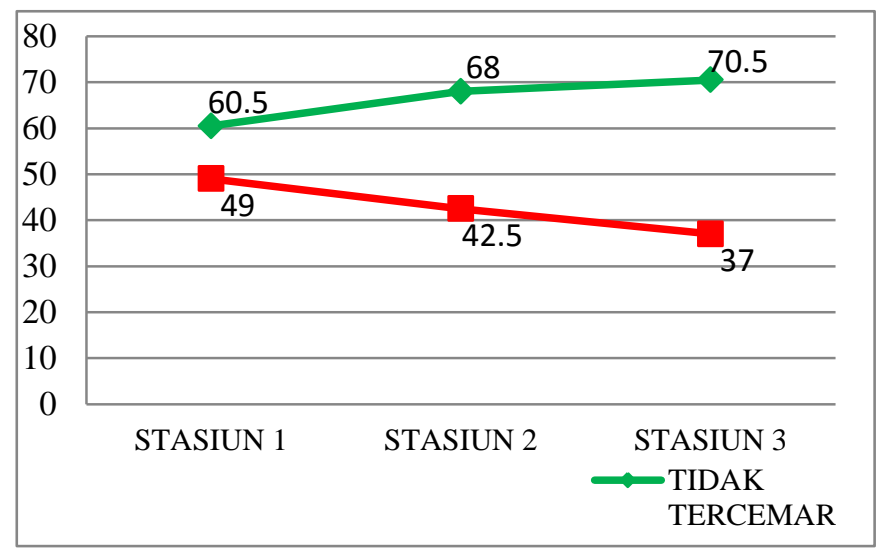

\section{Gambar 1. Perbandingan Rata-Rata Jumlah Stomata pada Lokasi yang Tercemar dan Lokasi Tidak Tercemar}

Pencemaran udara dapat terjadi akibat dihasilkan seperti asap, gas-gas beracun, kegiatan transportasi dan industri.Hasil ataupun partikulat debu yang dapat pembakaran dan kegiatan industri yang mencemari udara dan lingkungan di 
sekitarnya. Molekul pencemar yang di hasilkan antara lain terdiri dari $\mathrm{SO}_{2}, \mathrm{NO}_{2}$, $\mathrm{CO}_{2}, \mathrm{O}_{3}$, hidrokarbon, dan logam-logam berat seperti timbal $(\mathrm{Pb})$, seng $(\mathrm{Zn})$ dan cadmium $(\mathrm{Cd})$. Zat-zat yang terdapat pada emisi gas buang kendaraan berupa partikel debu baik dengan bentuk padat dan cairan yang dapat mengendap dalam partikel debu(Rachmawati, 2006).

Polutan yang dikeluarkan oleh kendaraan bermotor memberi dampak negatif pada tumbuhan. Pada tumbuhan dampak dari gas buang kendaraan terlihat dari rusaknya mesofil daun khususnya pada jaringan palisade dan berkurangnya jumlah stomata. Berdasarkan penelitian yang dilakukan oleh

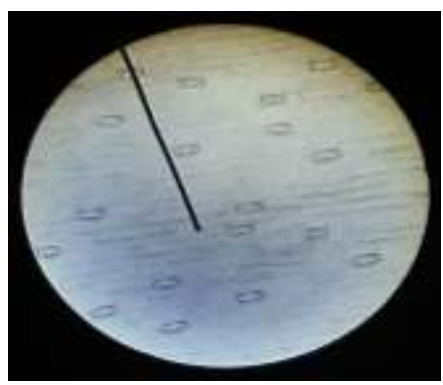

(a)
Sembiring (2006), menunjukan bahwa terdapat penurunan jumlah stomata pada daun S. macrophylla yang disebabkan oleh gas buang kendaraan bermotor. Kerusakan atau penurunan jumlah stomata terjadi akibat masuknya gas yang bersifat toksik melalui stomata dengan proses difusi, sehingga komposisi cairan yang ada di dalam sel menjadi terganggu dan sel menjadi rusak dan mati (Siregar, 2005).

Hasil penelitian menunjukkan, bahwa jumlah stomata pada lokasi yang tercemar polusi kendaraan lebih sedikit dibandingkan dengan lokasi yang tidak tercemar polusi (Gambar 2).

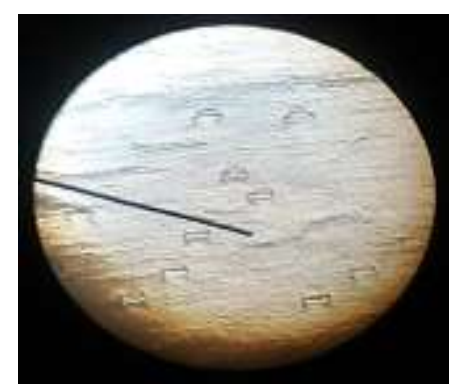

(b)

Gambar 2. Perbandingan Stomata pada Lokasi Tercemar Polusi (a) dan Lokasi Tidak tercemar Polusi (b)

Perbedaan jumlah stomata tersebut diduga karena adanya perbedaan kondisi lingkungan dan ketahanan stomata terhadap pencemar pada udara. Dampak paparan emisi pencemar pada lingkungan juga akan berpengaruh terhadap tanaman berupa rusaknya morfologi daun, kadar klorofil rendah dan kerapatan stomata serta tingginya persentase menutupnya celah stomata (Solihin, 2014).

Keadaan udara di sekitar tumbuhan berpengaruh terhadap stomata. Fungsi dari stomata, yaitu sebagai jalan pertukaran gas dan uap air antara tumbuhan dengan lingkungan sekitar (Tjitrosoepomo, 2005). Sehingga dari analisis karakteristik stomata pada daun tanaman Dracaena reflexadengan menggunakan metode pengolesan kutek (aceton) diduga pencemaran udara di sekitar jalan di kawasan Arjosari Kota Malang mempengaruhi jumlah stomata. Menurut Agustini (1994), dalam satu unit area permukaan daun kerapatan stomata sangat bevariasi. Hal ini disebabkan oleh perbedaan lingkungan tempat tumbuh dan faktor genetik yang sangat mempengaruhi perkembangan stomata.

Ketersediaan air, intensitas cahaya, suhu dan konsentrasi $\mathrm{CO}_{2}$ merupakan faktorfaktor yang mempengaruhi kerapatan stomata. Hasil penelitian ini sesuai dengan pernyataan Woodwart (1987) dalam Salisburi (1992) yang menyatakan, bahwa konsentrasi 
karbondioksida berpengaruh terhadap kerapatan stomata (pada proses transpirasi), yaitu jika jumlah karbondioksida meningkat, maka jumlah stomata persatuan luas akan lebih sedikit. Selain itu pencemaran udara juga dapat ditandai dengan melihat jumlah stomata yang terbuka, semakin banyak stomata yang terbuka maka semakin tinggi jumlah karbondioksida sebab karbaondioksida tersebut mempengaruhi proses pembukaan stomata.

\section{SIMPULAN DAN SARAN}

Berdasarkan hasil penelitian analisis karakteristik stomata pada tanaman Bambu Rejeki (Dracaena Reflexa) pada tempatyang terkena polusi dapat disimpulkan, bahwa karakteristik stomata pada tanaman Dracaena reflexa memiliki bentu oval dan didampingi oleh sel penutup yang berbentuk seperti ginjal dengan sel tetangga yang sejajar, tipe stomata Diasitik dan terdapat perbedaan jumlah stomata pada tiap lokasi penelitian. Jumlah stomata pada lokasi yang tercemar polusi udara lebih sedikit dibandingkan dengan lokasi yang tidak tercemar polusi udara.

Pada penelitian ini masih banyak kekurangan sehingga perlu dilakukan penelitian lebih lanjut mengenai karakteristik stomata pada lokasi yang berbeda. Selanjutnya perlu dilakukan penelitian lebih mendalam mengenai pengaruh polusi udara terhadap stomata pada tanaman di kawasan Arjosari Malang pada jenis tanaman yang berbeda.

\section{RUJUKAN}

Agustini, Maria. 1994. Identifikasi Ciri Arsitektur dan Kerapatan Stomata Dua Puluh Lima Jenis Pohon Suku Leguminosae untuk Elemen Lanskap Tepi Jalan. Skripsi. Bogor: Institut Pertanian Bogor.
Arisanti, Andini. 2005. Adaptasi Anatomi Pohon Roof Garden. Skripsi. Program Studi Arsitektur Lanskap. Fakultas Pertanian. Institut Pertanian Bogor. Bogor.

Fatia, N. L. Anisa, dkk. 2015. Analisis Kemampuan Tanaman Semak di Median Jalan dalam Menyerap Logam Berat Pb. Jurnal Produksi Tanaman, Volume 3, Nomor 7, Hlm. 528-534.

Hidayat, B, Estiti. 1995. Anatomi Tumbuhan Berbiji. Penerbit ITB. Bandung

Nasrullah, Nizar, dkk. 2000. Pengukuran Serapan Polutan Gas $\mathrm{NO}_{2}$ Pada

Tanaman Tipe Pohon, Semak dan Penutup Tanah dengan Menggunakan Gas $\mathrm{NO}_{2}$ Bertanda ${ }^{15} \mathrm{~N}$. Risalah Pertemuan Ilmiah Penelilian dan Pengembangan Teknologi Isotop dan Radiasi. Jakarta.

Pohan, Nurhasmawaty. 2002. Pencemaran Udara dan Hujan Asam. USU digital library.

Rachmawati.2006. Uji Pencemaran Udara oleh Partikulat Debu di Sekitar Terminal Lebak Bulus Berdasarkan Bioindikator Stomata pada Tanaman Glodokan (Polyalthia Longifolia). Universitas Islam Negeri Syarif Hidayatullah. Jakarta. (online): http://Rachmawati-fst.pdf.diakses tanggal 23 Mei 2017.

Salisbury, F.B. and C.W. Ross, 1992. Plant Physiology. Wards Worth Publishing Company Belmont California, $682 \mathrm{p}$.

Sembiring, Ebynthalina, dan Sulistyawati, Endang .2006. Akumulasi $\mathrm{Pb}$ dan Pengaruhnya pada Kondisi Daun Swietenia macrophylla King. Makalah Seminar Nasional Penelitian Lingkungan. Institut Teknologi Bandung. 
Vol. 2, No. 2 : Hal 7-12

September 2017

Siregar, Edy. B. M. 2005. Pencemaran Udara, Respon Tanaman, dan Pengaruhnya pada Manusia. Karya Ilmiah. Medan: Fakultas Pertanian Program Studi Kehutanan Universitas Sumatera Utara.

Solihin, A. 2014. Morfologi Daun, Kadar Klorofil, dan Stomata Glodokan Tiang
(Polyalthialongifolia) pada Daerah dengan Tingkat Paparan Emisi Kendaraan yang Berbeda di Yogyakarta. Skripsi. UIN Suka.

Tjitrosoepomo, Gembong. 2005. Morfologi Tumbuhan. Gadjah Mada University Press. Yogyakarta 